\title{
Photochemical reactions of metal nitrosyl complexes. Mechanisms of NO reactions with biologically relevant metal centers
}

\author{
Peter C. Ford \\ Department of Chemistry, University of California, Santa Barbara, CA 93106, USA
}

\begin{abstract}
The discoveries that nitric oxide (a.k.a. nitrogen monoxide) serves important roles in mammalian bioregulation and immunology have stimulated intense interest in the chemistry and biochemistry of NO and derivatives such as metal nitrosyl complexes. Also of interest are strategies to deliver NO to biological targets on demand. One such strategy would be to employ a precursor which displays relatively low thermal reactivity but is photochemically active to release NO. This proposition led us to investigate laser flash and continuous photolysis kinetics of nitrosyl complexes such as the Roussin's iron-sulfur-nitrosyl cluster anions $\mathrm{Fe}_{2} \mathrm{~S}_{2}(\mathrm{NO})_{4}{ }^{2-}$ and $\mathrm{Fe}_{4} \mathrm{~S}_{3}(\mathrm{NO})_{7}{ }^{-}$and several ruthenium salen and porphyrin nitrosyls. These include studies using metal-nitrosyl photochemistry as a vehicle for delivering NO to hypoxic cell cultures in order to sensitize $\gamma$-radiation damage. Also studied were the rates and mechanisms of NO "on" reactions with model water soluble heme compounds, the ferriheme protein met-myoglobin and various ruthenium complexes using ns laser flash photolysis techniques. An overview of these studies is presented.
\end{abstract}

\section{INTRODUCTION}

In the early 1990's, we initiated studies in this laboratory and collaboratively with the RIKEN (Japan) group of Mikio Hoshino into the photochemical reactions of metal nitrosyl complexes. This interest was stimulated by Larry Keefer and David Wink at the National Cancer Institute, who drew our attention to (then) recently discovered roles of nitric oxide as an intercellular bioregulatory agent in mammals and as a toxic species formed in immune response. Our involvement has grown into a major effort concerned with the photochemistry of nitrosyl complexes and with mechanistic investigations of related thermal reactions. Described here are several related projects concerned with the quantitative photochemistry of metal complexes, aspects of which are also concerned with fundamental chemical properties of $\mathrm{NO}$ or other reactive nitrogen oxide species having potential biological relevance.

The chemistry of nitric oxide was once largely the province of atmospheric science, although the interaction of NO and transition metals provided interesting textbook examples of coordination modes dependent upon electronic properties. However, the discoveries in the late 80 's that NO has key roles as a bioregulator in the cardiovascular system and in neurobiology and is formed in toxic concentrations during immune response to pathogens has induced considerable interest [1-3]. These roles and the apparent relationship of overor under-production of NO to various disease states has led to a remarkable outpouring of contributions to the chemical, biological and biomedical literature $[4,5]$. Nonetheless, despite this activity, fundamental issues regarding the condensed phase chemistries of $\mathrm{NO}$ and related species such as nitrogen dioxide $\left(\mathrm{NO}_{2}\right)$, peroxynitrite $\left(\mathrm{OONO}^{-}\right)$and hydrogen nitrosyl ( $\left.\mathrm{HNO}\right)$ need further analysis. For example, although metals are primary targets in the biological chemistry of NO, until recently little attention had been given to the mechanisms for the formation of metal-NO bonds.

Metal nitrosyls can also be seen as useful delivery agents of nitric oxide and, in particular, hold promise for the photochemical delivery of NO to biological targets. Photochemical delivery from thermally stable compounds would allow for specific targeting through control of irradiation areas and intensities. Since light transmission of mammalian tissues is more effective at longer wavelengths, complexes photosensitive to red light are of special interest.

Scheme 1 is a cartoon illustrating different strategies for NO photoproduction currently under study in this laboratory. The first two involve metal nitrosyl complexes, and there is a rich history of nitrosyl complex photochemistry, especially that involving metalloporphyrins [3]. The third (the "indirect method") generates NO not by labilization of an $\mathrm{M}-\mathrm{NO}$ bond but from the labilization of an $\mathrm{O}-\mathrm{N}$ bond of coordinated nitrite. Reviewed in the sections below are examples from each of these approaches.

\section{IRON SULFUR NITROSYL CLUSTERS (ROUSSIN'S ANIONS)}

Although the anions of Roussin's black salt, $\mathrm{Fe}_{4} \mathrm{~S}_{3}(\mathrm{NO})_{7}{ }^{-}$(RBS) and of Roussin's red salt, $\mathrm{Fe}_{2} \mathrm{~S}_{2}(\mathrm{NO})_{4}{ }^{2-}$ (RRS), were first described in the mid-19th century [7], their photochemistry has only recently drawn attention. The water soluble Roussin's 
DIRECT RELEASE

Metalloporphyrins

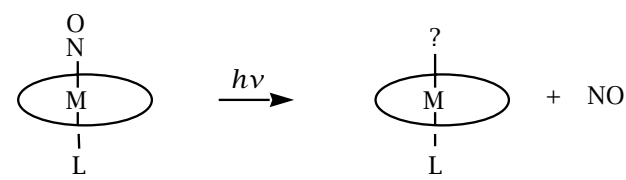

Other metal nitrosyls

$$
\mathrm{Fe}_{2} \mathrm{~S}_{2}(\mathrm{NO})_{4}^{2-} \stackrel{h v}{\longrightarrow} \mathrm{Fe}_{4} \mathrm{~S}_{3}(\mathrm{NO})_{7}^{-}+\mathrm{NO}+?
$$

SENSITIZED RELEASE

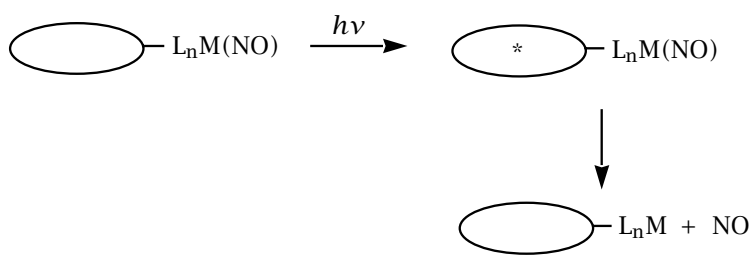

INDIRECT RELEASE

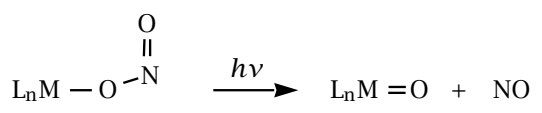

Scheme 1. Photochemical strategies for NO delivery.

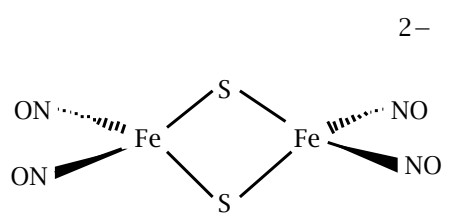

RRS

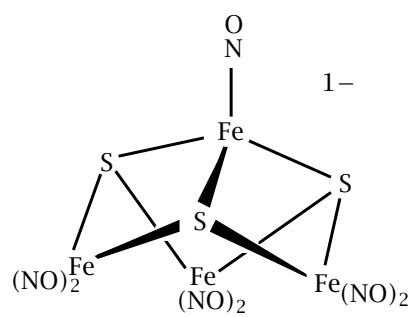

RBS salts were chosen to study in part because their optical spectra have absorptivities into the red, a feature attractive for possible use in tissues. The RBS anion has been the subject of several studies with vascular and brain tissues as a drug for the thermochemical or photochemical delivery of NO [8, 9]; indeed, a biological assay (rat tail artery relaxation) was used to demonstrate the NO release from RBS upon photolysis in buffer solutions [8]. The red salt anion RRS has primarily been studied as a synthetic precursor; for example, it reacts with haloalkanes to form red "esters", $\mathrm{Fe}_{2}(\mathrm{SR})_{2}(\mathrm{NO})_{4}$ [10]. The quantitative photochemistry of neither the anions nor the esters had received attention until our recent studies [11-14].

As their names imply, the Roussin's red and black salts are highly colored compounds with strong broad absorptions with moderately high extinction coeffi- cients $\left(1-3 \times 10^{3} \mathrm{M}^{-1} \mathrm{~cm}^{-1}\right)$ that suggest charge transfer character. There is clearly a need for a better understanding of the spectroscopy and photoactive excited states of these iron sulfur nitrosyl clusters, especially the lowest energy excited states (LEES), since the independence of quantum yields to the irradiation wavelength $\left(\lambda_{\text {irr }}\right)$ would be consistent with the cascade from initially formed states to a common LEES (see below). Extended Hückel molecular orbital calculations suggest that the LUMO has some $\mathrm{Fe}-\mathrm{Fe}$ and $\mathrm{Fe}-\mathrm{S}$ and $\mathrm{Fe}-\mathrm{NO}$ antibonding character $[15,16]$; hence excitation might be expected to lead to cluster fragmentation. However, in analogy to other iron sulfur clusters [17], the metal centers are likely to be antiferromagnetic coupled $\mathrm{Fe}^{3+}$ and/or $\mathrm{Fe}^{2+}$ with negatively charged nitrosyls. In such a case the LEES may be NO-to-iron charge transfer states with enhanced lability of the Fe - NO bonds. 
2.1. Photoreactions of RBS. Roussin's black salt is thermally stable in aerated aqueous solutions. Photolysis leads to optical density decreases broadly across the visible spectrum (Figure 1). The quantum yields for RBS disappearance $\left(\Phi_{\mathrm{d}}\right)$ for a variety of irradiation wavelengths $\left(\lambda_{\text {irr }}\right)$. These showed little dependence on $\lambda_{\text {irr }}$, giving an average $\Phi_{\mathrm{d}}$ value of $\sim 10^{-3}$ from $\lambda_{\text {irr }} 313$ to $546 \mathrm{~nm}$ in aerated aqueous solutions [12]. However, in deoxygenated solutions, RBS showed no net photochemistry when irradiated continuously, or upon repeated laser excitation. The importance of an oxidant to the net photochemistry is illustrated by the observation that solutions equilibrated with 1 atm $\mathrm{PO}_{2}$ gave quantum yields $\sim 5 \times$ that of air equilibrated solutions, in keeping with the higher $\left[\mathrm{O}_{2}\right]$.

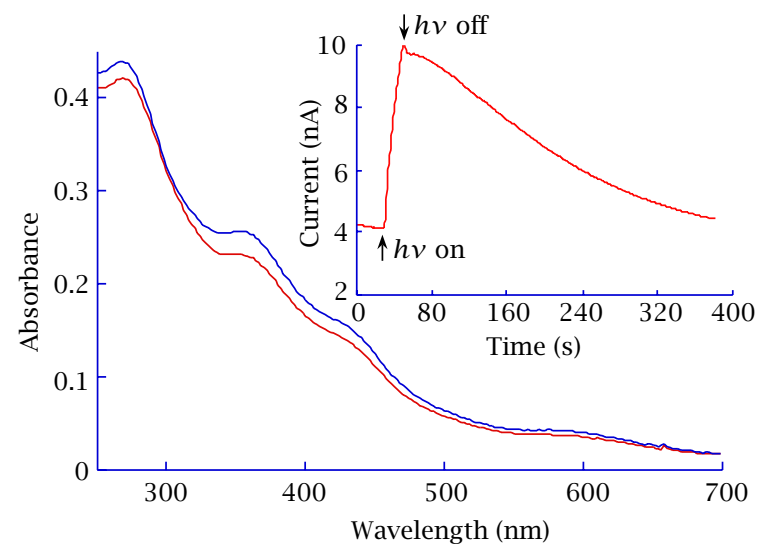

Figure 1. Spectral changes upon light photolysis of an aerated $\mathrm{pH} 7.0$ solution of Roussian's black salt. Inset: detection of NO released using a WPI NO sensor with calibrated sensitivity $0.66 n A / \mu M$. Initial $[\boldsymbol{R B S}]=15 \mu \mathrm{M} ; \Delta[\boldsymbol{R B S}]=$ $-1.51 \mu M . \Delta[\mathrm{NO}]$ determined electrochemically $=9.1 \mu \mathrm{M}$.

Electrospray mass spectroscopy (ESMS) was used to identify products of the black salt photolysis in aerated aqueous solution [12]. The RBS anion itself was well represented in the ESMS, showing both the parent at $530 \mathrm{~m} / \mathrm{z}$, as well as a series of three peaks showing losses of $\mathrm{NO}$ at successive $-30 \mathrm{~m} / \mathrm{z}$ intervals. Nitrite at $47 \mathrm{~m} / \mathrm{z}$ was also a primary product, accompanied by a weak nitrate peak at $63 \mathrm{~m} / \mathrm{z}$. Analysis for ferrous ions by 1,10 phenanthroline addition indicated nearly quantitative formation of ferrous ion and electrochemical experiments demonstrated that $\sim 6$ NO were released from each cluster, i.e., equation (1), (the unaccounted electron " $\left[e^{-}\right]$" is presumably consumed by $\mathrm{O}_{2}$ in these aerated media).

$$
\mathrm{Fe}_{4} \mathrm{~S}_{3}(\mathrm{NO})_{7}-\underset{\mathrm{O}_{2}}{\stackrel{h v}{\rightleftharpoons}} 3.9 \mathrm{Fe}^{2+}+5.9 \mathrm{NO}+3 \mathrm{~S}^{2-}+? .
$$

Flash photolysis studies of the RBS system have been carried out using time resolved optical (TRO) and time resolved infrared (TRIR) [18] spectroscopic techniques to probe the spectra and dynamics of possible reactive intermediates. Two transient species were formed in roughly equal concentrations, both of which are trapped by NO to reform RBS. In this context reaction sequence described in Scheme 2 was proposed where $\mathbf{X}$ and $\mathbf{Y}$ are considered to be isomers of the "unsaturated cluster" $\mathrm{Fe}_{4} \mathrm{~S}_{3}(\mathrm{NO})_{6}{ }^{-}$. The combined quantum yields $\left(\Phi_{X}+\Phi_{Y}\right)$ for formation of $\mathrm{X}$ and $\mathrm{Y}$ has a lower limit of 0.062 which can be compared to values of $<10^{-6}, 0.0011$ and 0.0042 determined in deaerated, aerated and oxygenated solutions, respectively, for the quantum yields ( $\Phi_{\text {RBS }}$ ) for RBS decomposition according to equation (1) under continuous photolysis conditions. The back reactions with NO have the second order rate constants $k_{\mathrm{NO}}{ }^{\mathrm{X}}=1.3 \times 10^{7} \mathrm{M}^{-1} \mathrm{~s}^{-1}$ and $k_{\mathrm{NO}}{ }^{\mathrm{Y}}=7 \times 10^{5} \mathrm{M}^{-1} \mathrm{~s}^{-1}$, and it is these rapid back reactions in competition with trapping by oxygen that determines the quantum yields for photodecomposition.

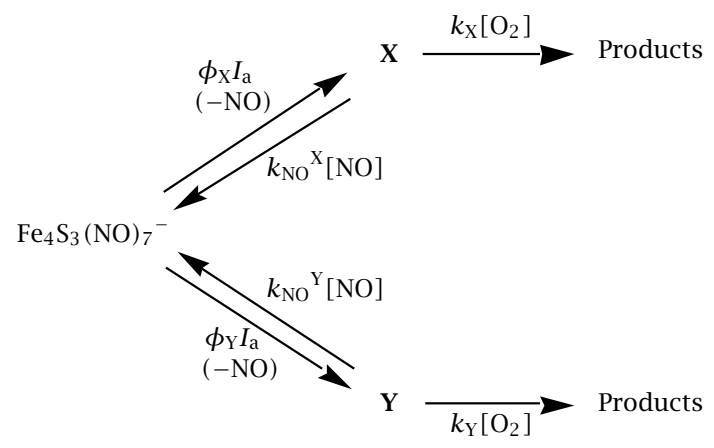

Scheme 2.

2.2. Photoreactions of RRS. Roussin's red salt anion is only moderately stable in aerated aqueous solutions at neutral $\mathrm{pH}$, and reacts to give RBS over the course of a few hours in the dark. When irradiated with near UV or visible light, this process was markedly accelerated and gives a $\lambda_{\text {irr }}$ independent quantum yield of $\sim 0.14$ for conversion of RRS [12]. The RBS product was identified from optical, FTIR and ESMS spectra: the latter also showed the formation of nitrite and sulfide. Electrochemical NO analysis indicated that 0.5 moles of NO are released for each mole of RRS converted to RBS.

Flash photolysis studies of Roussin's red salt dianion, $\mathrm{Fe}_{2} \mathrm{~S}_{2}(\mathrm{NO})_{4}{ }^{2-}$ (RRS) demonstrated high quantum yield formation of an intermediate believed to be $\mathrm{Fe}_{2} \mathrm{~S}_{2}(\mathrm{NO})_{3}{ }^{2-}$ formed by photodissociation of NO. This species reacts competitively with nitric oxide via second order kinetics $\left(k_{\mathrm{NO}}=9.1 \times 10^{8} \mathrm{M}^{-1} \mathrm{~s}^{-1}\right)$ to reform RRS and with dioxygen $\left(k_{\mathrm{Ox}}=5.6 \times 10^{7} \mathrm{M}^{-1} \mathrm{~s}^{-1}\right)$ to give a secondary intermediate [14]. The latter species is the likely precursor of the eventual photoproduct, $\mathrm{Fe}_{4} \mathrm{~S}_{3}(\mathrm{NO})_{7}{ }^{-}$(RBS). Scheme 3 illustrates the proposed scheme leading to these products. 


$$
\begin{gathered}
\mathrm{Fe}_{2} \mathrm{~S}_{2}(\mathrm{NO})_{4}{ }_{k_{\mathrm{NO}}=9.1 \times 10^{8} \mathrm{M}^{-1} \mathrm{~s}^{-1}} \underset{\phi_{1} \mathrm{I}_{\mathrm{a}}}{\mathrm{NO}}+\mathrm{Fe}_{2} \mathrm{~S}_{2}(\mathrm{NO})_{3}{ }^{2-}\left(\mathbf{I}_{\mathrm{i}}\right) \\
\mathrm{O}_{2} \\
k_{\mathrm{OX}}=5.7 \times 10^{7} \mathrm{M}^{-1} \mathrm{~s}^{-1} \\
\mathrm{Fe}_{2} \mathrm{~S}_{2}(\mathrm{NO})_{3}{ }^{-}\left(\mathbf{I}_{\mathrm{ii}}\right)
\end{gathered}
$$

Scheme 3.

The $\mathrm{Fe}_{2} \mathrm{~S}_{2}(\mathrm{NO})_{4}{ }^{2-}$ anion is also photoreactive in deaerated solutions, but with a much reduced $\Phi_{\mathrm{d}}$. In deaerated acetonitrile the Roussin's black salt dianion, $\mathrm{Fe}_{4} \mathrm{~S}_{3}(\mathrm{NO})_{7}{ }^{2-}$ (BSD) is the iron containing product as characterized by FTIR and UV-vis. However, in deoxygenated aqueous solutions only the RBS monoanion was observed, leaving our electron count incomplete. This discrepancy was eliminated by the discovery that under these conditions, $\mathrm{N}_{2} \mathrm{O}$ is also a reaction product with the $\Delta \mathrm{N}_{2} \mathrm{O} / \Delta \mathrm{RBS}$ ratio of $0.5 \pm 0.03$. This apparently comes from the direct reduction of NO by BSD $(\Delta E=+0.11 \mathrm{~V})$ to give the nitroxyl anion, $\mathrm{NO}^{-}$, followed by formation of nitrous oxide in protic solvents $\left(2 \mathrm{NO}^{-}+2 \mathrm{H}^{+} \rightarrow \mathrm{H}_{2} \mathrm{O}+\mathrm{N}_{2} \mathrm{O}\right)$. The following stoichiometry in deaerated protic solvents results.

$$
\begin{aligned}
2 \mathrm{H}^{+} & +4 \mathrm{Fe}_{2} \mathrm{~S}_{2}(\mathrm{NO})_{4}{ }^{2-} \\
& \stackrel{h v}{\longrightarrow} 2 \mathrm{Fe}_{4} \mathrm{~S}_{3}(\mathrm{NO})_{7}{ }^{-}+2 \mathrm{~S}^{2-}+\mathrm{N}_{2} \mathrm{O}+\mathrm{H}_{2} \mathrm{O} .
\end{aligned}
$$

2.3. Radiation sensitization using RRS. The use of these complexes to deliver NO to biological targets was the subject of collaborative studies at the Radiation Biology Branch at the National Cancer Institute in Bethesda, MD [12]. Nitric oxide has long been known to sensitize hypoxic (oxygen deficient) cell cultures to gamma radiation damage [19]. The Roussin's salts were therefore used to deliver NO photochemically to hypoxic cultures of Chinese hamster V79 cells in order to probe possible effects upon the $\gamma$-radiation sensitivity of these cells.

Figure 2 shows the logarithmic survival rate of the cell cultures when subjected to varied irradiation doses. As can be clearly observed, treatment of the cells with RRS had little effect on the survival, but simultaneous white light irradiation greatly decreased the survival fractions of the cell cultures when exposed to $\gamma$ radiation. Visible light irradiation of the RRS incubated cell cultures without $\gamma$-radiation, had little effect on survival fractions. Sensitization up to 100 fold of radiation induced cell death was observed for this and other red salt concentrations. These results clearly provide a proof-of-concept example for delivery of NO to biological targets by photochemical means.

2.4. Roussin's Red “Esters". We have extended these investigations to various sulfur functionalized

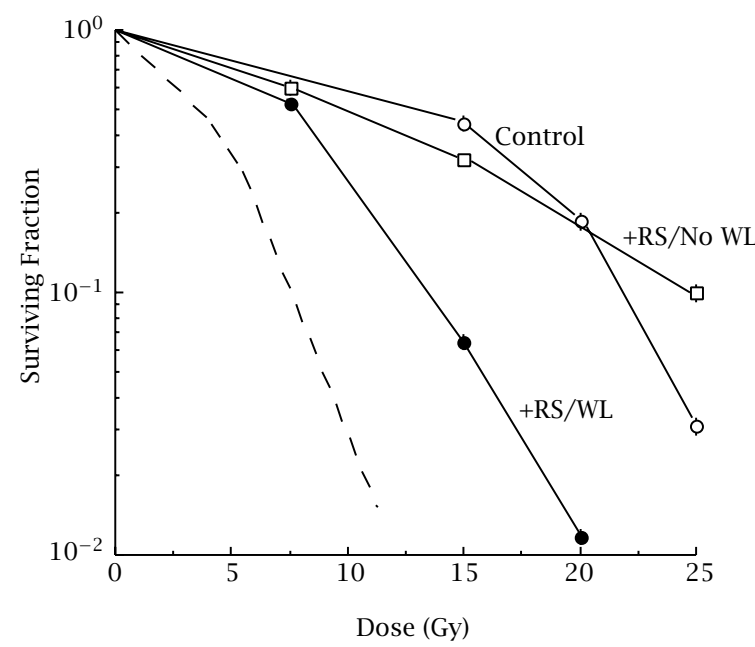

Figure 2. Survival of V79 cells exposed to y radiation under hypoxic conditions in the absence (open circles) or presence of $500 \mu \mathrm{M}$ RRS with (closed circles) or without (open squares) light exposure. The dashed line on the plot indicates the responce of cells exposed to $\gamma$ radiation under fully aerobic conditions.

derivatives $\mathrm{Fe}_{2}(\mathrm{SR})_{2}(\mathrm{NO})_{4}$, the Roussin's red esters RSE [20], which are more air stable than RRS yet remain photoactive toward NO dissociation. These can be prepared from the reaction of RRS with the precursor R-X. Of particular interest is the possibility of varying the group $R$ to manipulate the properties such as reactivity, solubility, optical spectral profile or biological specificity of a unit containing the iron sulfur clusters.

For example, the sulfonated derivative, $\mathrm{Na}_{2}\left[\mathrm{Fe}_{2}\right.$ $\left.\left(\mathrm{SCH}_{2} \mathrm{CH}_{2} \mathrm{SO}_{3}\right)_{2}(\mathrm{NO})_{4}\right]$ shows both good thermal stability and high water solubility. The photolysis of this complex in aerated solutions results in the formation of 3.8 moles of NO per mole of complex photoconverted. The other products included $\mathrm{Fe}^{2+}$ ions and the free thiol ligands, observed by ESMS. The quantum yield for NO formation $\Phi_{\mathrm{NO}}$ in aerated aqueous solution is $\sim 0.2$, the highest value for a Fe $-\mathrm{S}-\mathrm{NO}$ complex yet observed. However, these RRS esters have electronic spectra similar to that of RRS itself and do not adsorb sufficiently at longer wavelengths for in vivo studies.

To address this issue we are preparing other RRE compounds where the R-groups have a chromophore<smiles>[R][S]1[SH]([R])[Z8]1([N+](=O)[O-])[N+](=O)[O-]</smiles> 
such as a dye molecule which might act as an intramolecular photosensitizer of the $\mathrm{Fe}_{2} \mathrm{~S}_{2}(\mathrm{NO})_{4}$ moiety. For example, we have now prepared [20] the RRS ester with $R_{2}=$ a derivative of protoporphyrin IX (PPIXRSE) and have characterized it by a number of physical methods including high resolution mass spectrometry. Although the absorption spectra is almost entirely dominated by the porphyrin chromophore, the photophysics and photochemistry of this species are strongly influenced by the presence of the Roussin's cluster. The intensity of emission from the free base porphyrin is $\sim 90 \%$ quenched and the lifetime is correspondingly shorter. Furthermore, direct excitation of the porphyrin Q-band absorptions with $546 \mathrm{~nm}$ light leads to NO release from the cluster with a quantum yield clearly consistent with intramolecular photosensitization of reactions at the RRS cluster center.

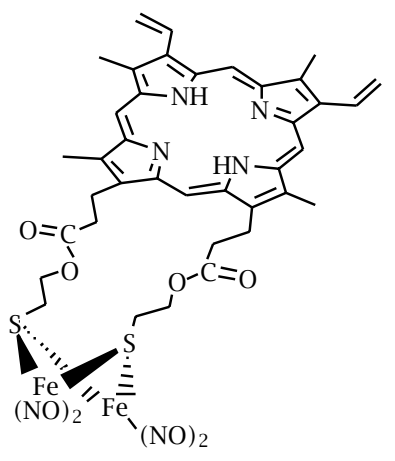

RSE-PPIX

\section{PHOTOREACTIONS OF RUTHENIUM NITROSYL PORPHYRINS}

Thermal stability is a necessary characteristic for a photoactive NO carrier. It was this feature that turned our attention to the ruthenium porphyrin complexes $\mathrm{Ru}(\mathrm{P})(\mathrm{X})(\mathrm{NO})$ (e.g., $\mathrm{P}=\mathrm{TPP}$ (tetraphenylporphyrin) or OEP (octaethylporphyrin)) since ruthenium nitrosyls are generally robust. Porphyrins have strong absorptions in the red, thus $\mathrm{M}(\mathrm{P}) \mathrm{NO}$ species may have attractive properties in this regard. These were first prepared by the reaction shown in equation (3) [21, 22], and quantitative kinetics studies of this transformation provided a valuable platform for characterizing one mechanism for metal promoted NO disproportionation [23].

$$
\mathrm{Ru}(\mathrm{P})(\mathrm{CO})+4 \mathrm{NO} \longrightarrow \mathrm{Ru}(\mathrm{P})(\mathrm{NO})(\mathrm{ONO})+\mathrm{CO}+\mathrm{N}_{2} \mathrm{O} \text {. (3) }
$$

The photochemistry of various $\mathrm{Ru}(\mathrm{P})(\mathrm{NO})(\mathrm{X})$ is quite rich owing to competitive excited state reactions [24]. For example, flash photolysis studies of $\mathrm{Ru}(\mathrm{TPP})(\mathrm{NO})(\mathrm{ONO})$ (A) in hydrocarbon solvents demonstrated that two short-lived intermediates are formed. The decay kinetics clearly demonstrated that the temporal absorbance could be best fit to two exponentials. both of which are [NO] dependent (Figure 3). We have shown that one photoreaction is NO labilization to give (formally) a $\mathrm{Ru}(\mathrm{III})$ intermediate $\mathrm{Ru}(\mathrm{P})(\mathrm{ONO})$. This is reversible and displays a back reaction with $\mathrm{NO}$ with a second order rate constant of $2.8 \times 10^{8} \mathrm{M}^{-1} \mathrm{~s}^{-1}$. The other involves $\mathrm{NO}_{2}$ dissociation to give the transient paramagnetic species $\mathrm{Ru}(\mathrm{P})(\mathrm{NO})$ having analogy in stable complexes formed from simple $\mathrm{NO}$ addition to $\mathrm{Fe}^{\mathrm{II}}(\mathrm{P})$. Dissociation of $\mathrm{NO}_{2}$ is also a photoreaction of the manganese nitrito complex Mn(TPP) (ONO) (see below) [25]. That $\mathrm{NO}_{2}$ dissociation is seen indicates the electronic flexibility of the $\mathrm{Ru}(\mathrm{P})(\mathrm{NO})$ chromophore, since this (formally) involves reduction of a $\{\mathrm{MNO}\}^{6}$ to a $\{\mathrm{MNO}\}^{7}$ system [26]. The return of this intermediate to the starting nitrosyl nitrito species is a complicated transformation, involving formation of the dinitrosyl complex $\mathrm{Ru}(\mathrm{P})(\mathrm{NO})_{2}$

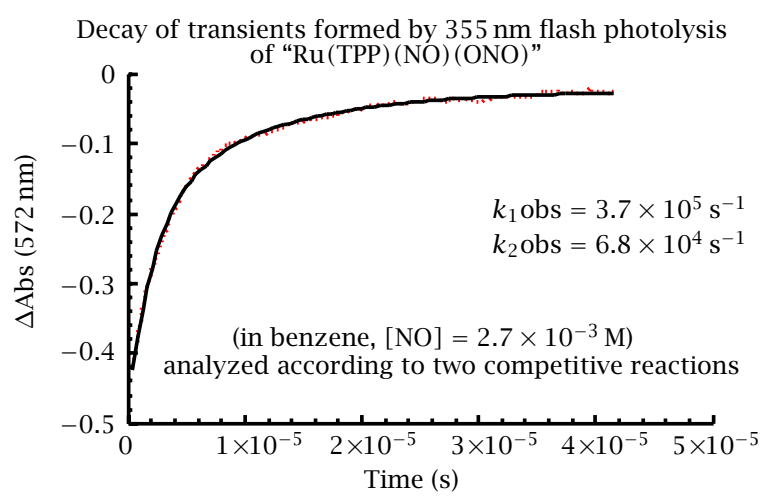

Figure 3. Decay of transients formed by laser flash photolysis of $\mathrm{Ru}(\mathrm{TPP})(\mathrm{NO})(\mathrm{ONO})$ in benzene solution as monitored in the $Q$-band region.

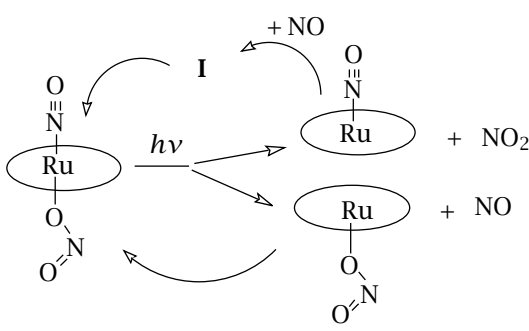

Scheme 4.

(I) via a second order reaction of $\mathrm{Ru}(\mathrm{P}) \mathrm{NO}$ with $\mathrm{NO}$ $\left(2 \times 10^{7} \mathrm{M}^{-1} \mathrm{~s}^{-1}\right)$ followed by further reaction with $\mathrm{NO}$ to give $\mathrm{Ru}(\mathrm{P})(\mathrm{NO})(\mathrm{ONO})$ plus $\mathrm{N}_{2} \mathrm{O}$ in analogy to the thermal reaction of $\mathrm{Ru}(\mathrm{P})(\mathrm{CO})$ with $\mathrm{NO}$ to give $\mathrm{A}, \mathrm{CO}$ and $\mathrm{N}_{2} \mathrm{O}$ [23] (Scheme 4).

\section{RUTHENIUM SALEN NITROSYL COMPLEXES}

We have begun to explore another synthetic platform 

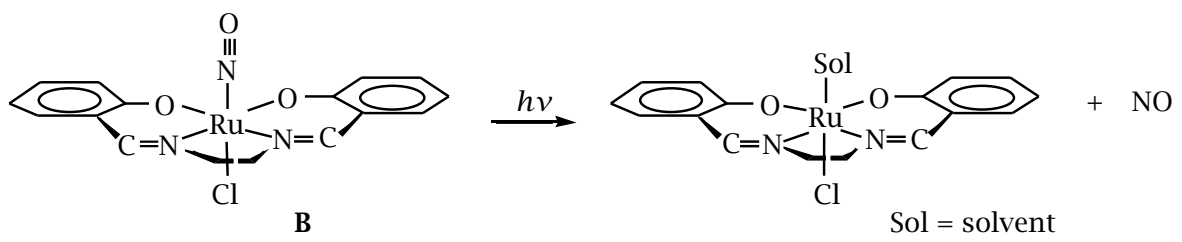

for ruthenium based NO carriers, namely, the salentype complexes $\mathrm{Ru}(\mathrm{R}-$ salen$)(\mathrm{X})(\mathrm{NO}),\left(\right.$ salen $=\mathrm{N}, \mathrm{N}^{\prime}$ bis(salicylidene)-ethylenediaminato dianion). Additional interest in these derives from recent demonstrations that $\mathrm{Ru}(\mathrm{R}-$ salen $)(\mathrm{X})(\mathrm{NO})$ compounds are precursors of oxene and carbene transfer catalysts for alkene asymmetric epoxidations and cyclopropanations as well as of Lewis acid catalysts for asymmetric hetero Diels-Alder reactions [27]. Since these catalysts are activated by light, quantitative evaluation of their photochemical properties has multi-dimensional interest.

We have carried out preliminary photoreactivity investigations on a representative member of this family, $\mathrm{Ru}$ (salen) (Cl) (NO) (B) in various media [28]. These demonstrate that NO is labilized at $436 \mathrm{~nm}$ ) to give solvento $\mathrm{Ru}(\mathrm{III})$ analogs (equation (4)) and provide a logical model for the photoactivation and solvent dependent reactivities of the catalysts noted above.

The thermal reverse reaction to regenerate $\mathbf{B}$ (equation (5)) is strongly dependent on the nature of the solvent, with second order rate constants $k_{\mathrm{NO}}(298 \mathrm{~K})$ ranging $\sim 11$ orders of magnitude from $4 \times 10^{7} \mathrm{M}^{-1} \mathrm{~s}^{-1}$ in toluene to $\sim 5 \times 10^{-4} \mathrm{M}^{-1} \mathrm{~s}^{-1}$ in acetonitrile [28]. Superficially, this observation suggests a mechanism where Sol dissociation from the $\mathrm{Ru}$ (III) center is occurring or has occurred at the rate limiting transition state for Ru - NO bond formation. Such a pathway is consistent with the mechanism we proposed for the NO reactions with ferri-heme models and metmyoglobin based on activation parameters measurements [31-33]. However, this mechanism is inconsistent with studies carried out on $\mathrm{NO}$ substitution for $\mathrm{NH}_{3}$ on the $\mathrm{Ru}$ (III) complex $\mathrm{Ru}\left(\mathrm{NH}_{3}\right)_{6}{ }^{3+}$ in aqueous solution. In that case, the second order reaction of $\mathrm{NO}$ is too fast to be attributed to $\mathrm{NH}_{3}$ dissociation and activation parameters are consistent with associative attack of the NO radical on the d5 metal center [34].

$$
\begin{aligned}
\mathrm{Ru}(\text { salen})(\mathrm{Cl})(\mathrm{Sol}) & +\mathrm{NO} \\
& \stackrel{k_{\mathrm{NO}}}{\longrightarrow} \mathrm{Ru}(\text { salen })(\mathrm{Cl})(\mathrm{NO})+\text { Sol. }
\end{aligned}
$$

Another example of this family is Ru(salen) (NO) (ONO) described by Wilkinson et al. [29]. In contrast to the porphyrin analog $\mathbf{A}$, photochemical studies of this indicate the formation of a single intermediate, $\mathrm{Ru}$ (salen) $(\mathrm{ONO})(\mathrm{Sol})$ (Sol = solvent) generated by NO loss [30]. In preliminary studies, we have also developed procedures for the synthesis of the ionic compounds $\left[\mathrm{Ru}\right.$ (salen) $\left.\left(\mathrm{H}_{2} \mathrm{O}\right)(\mathrm{NO})\right] \mathrm{X}$ and have demonstrated that their photochemistry in aqueous solution is analogous to that of $\mathbf{B}$ [30].

The salen type ligands are easily modified to change the electronic and steric characteristics of the ligands. In this context, we are beginning an exploratory effort to engineer new molecular species of the type $\mathrm{Ru}(\mathrm{L})(\mathrm{X})(\mathrm{NO})$ ( $L=$ various salen-type ligands) with initial goals of tuning the spectroscopic properties. For example, standard salen complexes have relatively low absorptivities in the visible region (Figure 4, dashed line); while those of the more conjugated salophen ligands (see drawing) show much stronger bands in the red (Figure 4 solid line), yet qualitatively have photoreactivity properties similar to those of $\mathbf{B}$ [27]. The goal is to prepare and characterize a related series of new compounds where systematic variations lead to predictable differences in the absorption spectra, solubilities and photochemical reactivities.

4.1. Photochemistry of $\mathrm{Mn}(\mathrm{III})$ and $\mathrm{Cr}(\mathrm{III})$ nitrito complexes. This project is an example of serendipity. We were interested in demonstrating NO formation from the photochemical cleavage of an $\mathrm{O}-\mathrm{N}$ bond of coordinated nitrite $(\mathrm{M}-\mathrm{O}-\mathrm{NO} \rightarrow \mathrm{M}=\mathrm{O}+\mathrm{NO})$. This was an early suggestion for one of the photoreaction pathways of $\mathrm{Ru}(\mathrm{P})(\mathrm{NO})(\mathrm{ONO})$ and had been described

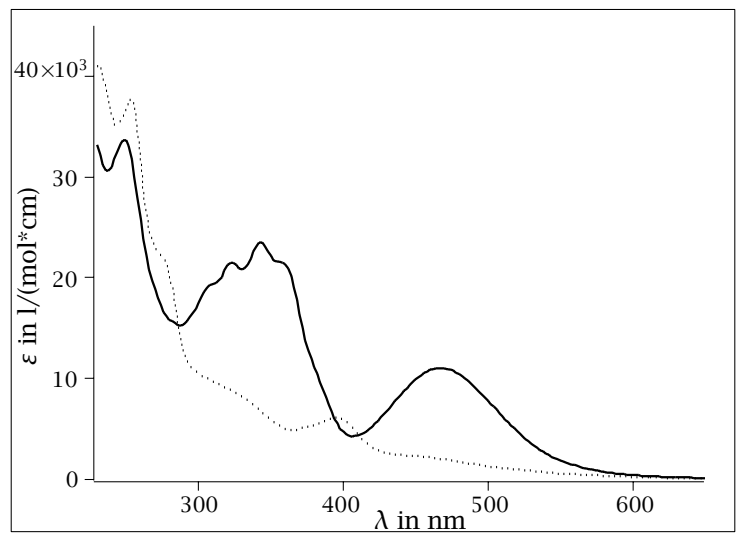

Figure 4. Optical Spectra of $t$-Bu derivatives of $\boldsymbol{B}$ (dashed line) and its salophen analog (solid line) in acetonitrile solution. 


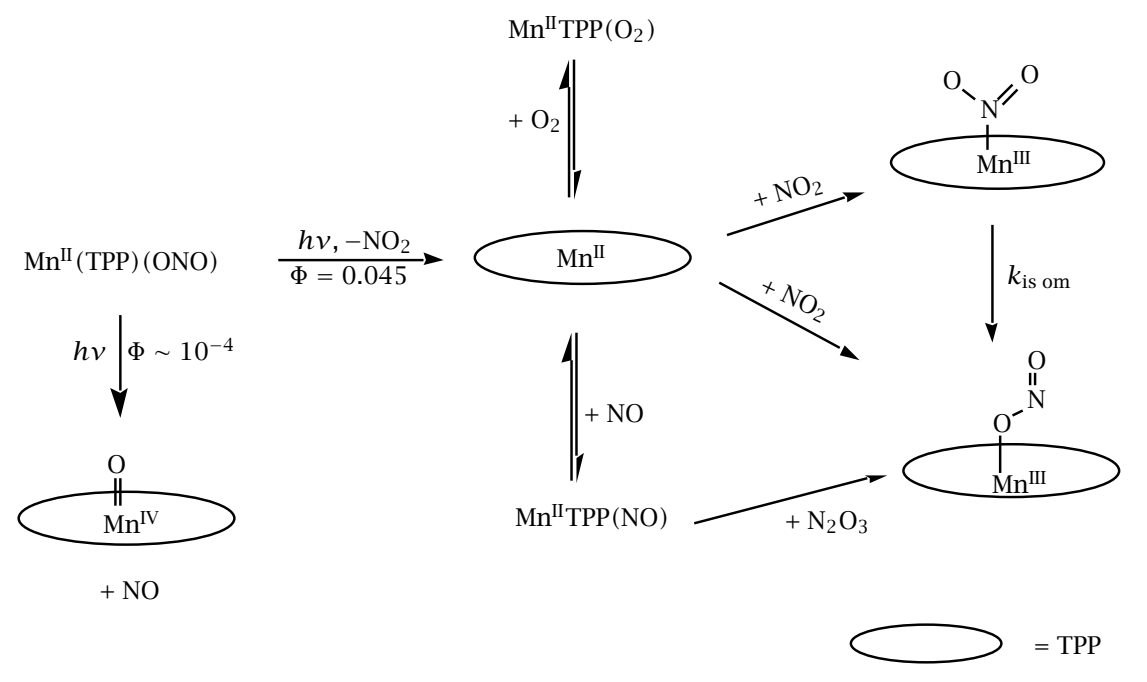

Scheme 5.

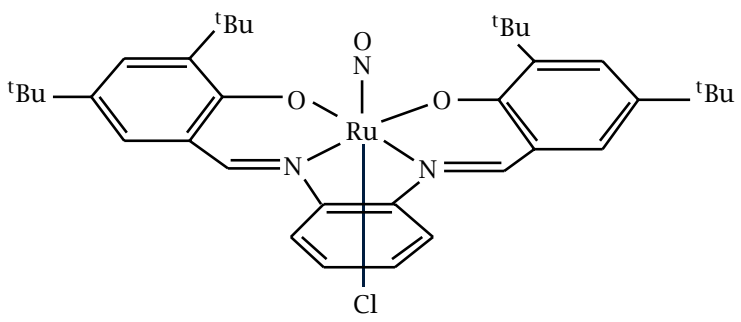

$\mathrm{Ru}\left((\mathrm{tBu})_{4}\right.$ salophen) $(\mathrm{Cl})(\mathrm{NO})$

as a pathway for the photolysis of $\mathrm{Mn}(\mathrm{TPP})(\mathrm{ONO})(\mathrm{C})$ [34]. However, when we (with Hoshino) examined the flash photolysis kinetics of $\mathbf{C}$ [25], the dominant photoreaction was homolytic cleavage of the $\mathrm{M}-\mathrm{O}$ bond to give $\mathrm{NO}_{2}(\Phi=0.045)$ accompanied by formation of the $\mathrm{Mn}$ (II) intermediate Mn(TPP). While this provided the opportunity to examine the quantitative reactivities of $\mathrm{Mn}$ (TPP) with $\mathrm{NO}, \mathrm{O}_{2}$ and $\mathrm{NO}_{2}$ (Scheme 5), it also piqued our interest in exploring what parameters would lead to the photolytic generation of NO from O-coordinated nitrite. It had been previously shown that the porphyrin complexes $\mathrm{Mo}(\mathrm{TPP})(\mathrm{O})(\mathrm{ONO})$ and $\mathrm{Cr}(\mathrm{TPP})(\mathrm{ONO})$ undergo irreversible $\beta$-cleavage to give $\operatorname{Mo}(\mathrm{TPP})(\mathrm{O})_{2}$ and $\mathrm{Cr}$ (TPP) (O) in benzene [35].

Hoshino's results with $\mathrm{Cr}$ (TPPP)(ONO) [35] clearly suggested that with a sufficiently oxophilic metal, coordinated nitrite can serve as a photochemical NO precursor. In this context, we turned to the amine complexes of $\mathrm{Cr}(\mathrm{III})$ to see if this behavior had generality beyond the metalloporphyrins. Another attractive property of these is the solubility in water, a feature likely to be desirable in biomedical applications. The first of such species examined was $\mathrm{Cr}\left(\mathrm{NH}_{3}\right)_{5}(\mathrm{ONO})^{2+}$. The optical absorption spectrum of this is defined by the Laporte forbidden ligand field (d-d) transitions at $482 \mathrm{~nm}\left(\varepsilon=43 \mathrm{M}^{-1} \mathrm{~cm}^{-1}\right)$ and $356 \mathrm{~nm}$ with an intensity $\left(37 \mathrm{M}^{-1} \mathrm{~cm}^{-1}\right)$ consistent with the next higher energy quartet band but in the region where the internal ligand $n-\pi^{*}$ band of the nitrito functionality is expected. When freshly prepared aqueous solutions ( $1 \mathrm{mM}, \mathrm{pH} 7)$ were irradiated with the white light from a $75 \mathrm{~W}$ high pressure xenon arc lamp, NO formation was monitored electrochemically. Quantum yields were not evaluated owing to the instability of this species to thermal reactions under photolysis conditions. Furthermore, it was apparent that the $\mathrm{Cr}\left(\mathrm{NH}_{3}\right)_{5}(\mathrm{ONO})^{2+}$ ion was undergoing other photochemistry, namely labilization the ammine trans to the nitrito ligand [36].

Our attention then turned to the $\mathrm{Cr}$ (III) complex trans-Cr $($ cyclam $)(\mathrm{ONO})_{2}{ }^{+}(\mathbf{D}$, cyclam $=1,4,8,11$ tetraazacyclotetradecane) (Figure 5). When D was subjected to continuous photolysis $\left(\lambda_{\text {irr }}=436 \mathrm{~nm}\right)$ in deaerated pH 7 aqueous solution (or under an Ar or NO atmosphere), a gradual shift of the absorption spectrum to that of the trans- $\mathrm{Cr}^{\mathrm{III}}($ cyclam $)\left(\mathrm{H}_{2} \mathrm{O}\right)(\mathrm{ONO})^{+}$ cation was observed. The spectral changes closely match those seen in the acid hydrolysis of $\mathbf{D}$ at $\mathrm{pH} 2$, and are analogous to those reported for the acid hydrolysis of trans- $\left[\mathrm{Cr}(\mathrm{en})_{2}(\mathrm{ONO})_{2}\right]^{+}$. Thus, we conclude that the net photoreaction under these conditions is simple photoaquation with a small quantum yield $\left(\Phi_{\mathrm{aq}}=0.0092 \pm 0.0008\right)$. This is consistent with the very low photoreactivity that has been noted for other trans$\mathrm{Cr}($ cyclam $) \mathrm{X}_{2}{ }^{+}$cations (e.g., $\mathrm{X}=\mathrm{Cl}$ ) when subjected to ligand field excitation.

The spectral changes were entirely different when D was photolyzed in aerated aqueous solutions at different $\lambda_{\text {irr }}$ ranging from $365 \mathrm{~nm}$ to $546 \mathrm{~nm}$. A new species ws identified provisionally as 


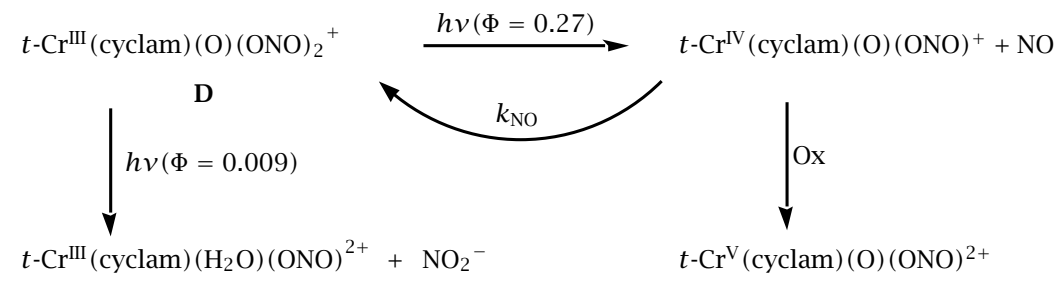

E

Scheme 6 .

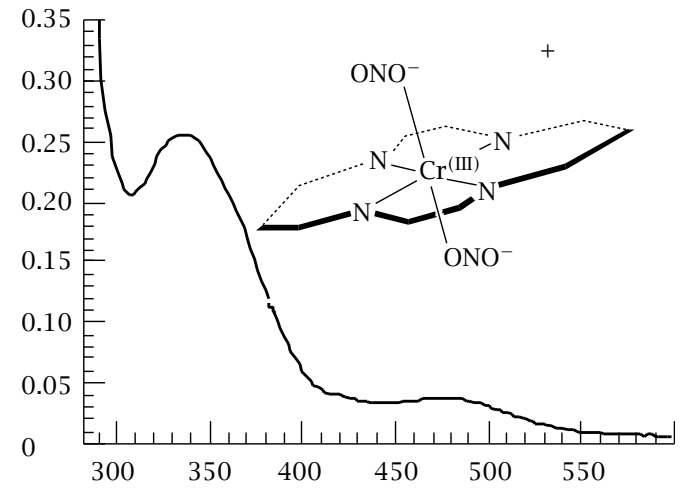

Figure 5. Spectrum of trans-Cr(cyclam $)(\mathrm{ONO})_{2}{ }^{+}$in aqueous solution.

trans $-\mathrm{Cr}^{\mathrm{IV}}$ (cyclam) $(\mathrm{O})(\mathrm{ONO})^{+}$, which was trapped by oxygen to give the $\mathrm{Cr}^{\mathrm{V}}$ complex $\mathbf{E}$ with an overall quantum yield of 0.27 at $436 \mathrm{~nm}$. NO formation was confirmed electrochemically, and flash photolysis indicated that the primary photoproduct reacts readily with NO $\left(k_{\mathrm{NO}}=3.1 \times 10^{6} \mathrm{M}^{-1} \mathrm{~s}^{-1}\right)$ to reform $\mathbf{D}$ in competition with $\mathrm{O}_{2}$ trapping to give E. (Scheme 6) [36].

\section{SUMMARY}

This article has summarized recent studies in this laboratory which have been concerned with the photochemistry of metal nitrosyls. Work on the Roussin's salts has demonstrated the concept of coordination complexes as photochemical NO delivery agents to biological targets, leading to sensitization of cell to $\gamma$ radiation damage. Ongoing flash photolysis studies to elucidate mechanisms for the photochemical reactions of the black and red salts have been summarized. The ester complexes such as, $\mathrm{Fe}_{2}(\mathrm{SR})_{2}(\mathrm{NO})_{4}$, especially those with red sensitive chromophores hold considerable promise as more effective delivery agents. The ruthenium nitrosyl complexes such as the porphyrins are very stable and release NO upon photolysis However the salen type complexes are potentially more attractive owing to the ability to easily tune the spectroscopic and reactivity properties by modifying the ligands. Lastly were described several complexes of oxophilic metals that activate the nitrite ion toward photodecomposition.

\section{ACKNOWLEDGMENTS}

This work was supported by the National Science Foundation (CHE 9400919 and CHE 9726889) and by a Collaborative UC/Los Alamos Research (CULAR) Initiative grant from Los Alamos National Laboratory. TRO experiments were carried out on systems constructed with instrumentation grants from the U.S. Department of Energy University Research Instrumentation Grant Program (No. DE-FG-05-91ER79039) and from the National Science Foundation. The following students and postdoctoral fellows in my laboratory have contributed to the studies described in this review: Katrina M. Miranda, Brian Lee, James L. Bourassa, Malcolm DeLeo, Carmen Works, Christa Conrado, Dr. Setsuko Kudo, and Dr. Ivan Lorkovic. I also thank Dr. David Wink of the National Cancer Institute (Bethesda MD, USA) and Dr. Mikio Hoshino (RIKEN, Japan) with whom we have collaborated.

\section{References}

[1] S. Moncada, R. M. J. Palmer, and E. A. Higgs, Pharmacol. Rev. 43 (1991), 109.

[2] Methods in Nitric Oxide Research; J. Wiley and Sons, M. Feelish and J. S. Stamler (eds.), Chichester, England, 1996 and references therein.

[3] (a) P. L. Feldman, O. W. Griffith, and D. J. Stuehr, Chem. Eng. News 71 (1993), 10, 26. (b) D. A. Wink, I. Hanbauer, M. B. Grisham, F. Laval, R. W. Nims, J. Laval, J. Cook, R. Pacelli, J. Liebmann, M. Krishna, P. C. Ford, and J. B. Mitchell, Current Topics in Cellular Regulation 34 (1996), 159.

[4] Nitric Oxide: Biology and Pathobiology, L. J. Ignarro (ed.), Academic Press, San Diego, 2000.

[5] "Nitric Oxide and Infection", F. C. Fang (ed.), Kluwer Academic/Plenum Publishers, New York, 1999.

[6] a) E. G. Moore and Q. H. Gibson, J. Biol. Chem. 251 (1976), 2788. 
b) E. J. Rose and B. Hoffman, J. Am. Chem. Soc. 105 (1983), 2866.

c) M. Hoshino, S. Arai, M. Yamaji, and Y. Hama, J. Phys. Chem. 90 (1986), 2109.

d) M. Hoshino and M. Kogure, J. Phys. Chem. 93 (1989), 5478 and references therein.

e) J. W. Petrich, C. Poyart, and J. L. Martin, Biochemistry 27 (1988), 4049.

f) S. Georgio and C. A. Wight, J. Phys. Chem. 94 (1990), 4935.

g) K. A. Jongeward, D. Magde, D. J. Taube, J. Marsters, T. G. Traylor, and V. S. Sharma, J. Am. Chem. Soc. 110 (1988), 380.

h) T. G. Traylor, D. Magde, J. Marsters, K. Jongeward, G.-Z. Wu, and K. Walda, J. Am. Chem. Soc. 115 (1993), 4808.

i) E. A. Morlino and M. A. J. Rodgers, J. Am. Chem. Soc. 118 (1996), 11798.

j) J. I. Zink, Photochem. Photobiol. 65 (1997), 65, and references therein.

[7] A. R. Butler, C. Glidewell, and M-H Li, Adv. Inorg. Chem. 32 (1988), 335.

[8] F. W. Flitney, I. L. Megson, J. L. M. Thomson, G. D. Kennovin, and A. R. Butler, Br. J. Pharmacol. 117 (1996), 1549.

[9] E. K. Matthews, E. D. Seaton, M. J. Forsyth, and P. P. A. Humphrey, Br. J. Pharmacol. 113 (1994), 87.

[10] T. B. Rauchfuss and T. D. Weatherill, Inorg. Chem. 21 (1982), 827.

[11] J. Bourassa, W. DeGraff, S. Kudo, D. A. Wink, J. B. Mitchell, and P. C. Ford, J. Am. Chem. Soc. 119 (1997), 2853.

[12] S. Kudo, J. L. Bourassa, S. E. Boggs, Y. Sato, and P. C. Ford, Analytical Biochemistry 247 (1997), 193.

[13] J. Bourassa, B. Lee, S. Bernard, J. Schoonover, and P. C. Ford, Inorg. Chem. 38 (1999), 2947.

[14] J. Bourassa and P. C. Ford, Coord. Chem. Revs. 200202 (2000), 887.

[15] S.-S. Sung, C. Glidewell, A. R. Butler, and R. Hoffman, Inorg. Chem. 24 (1985), 3856.

[16] S. D’Addario, F. Demartin, L. Grossi, M. C. Iapalucci, F. Laschi, G. Longoni, and P. Zanello, Inorg. Chem. 32 (1993), 1153.

[17] L. Noodleman and E. J. Baerends, J. Am. Chem. Soc. 106 (1984), 2316.

[18] P. C. Ford, J. Bridgewater, and B. Lee, Photochem. Photobiol. 65 (1997), 57.
[19] a) P. Howard-Flanders, Nature (London) 180 (1957), 1191.

b) J. B. Mitchell, D. A. Wink, W. DeGraff, J. Gamson, L. K. Keefer, and M. C. Krishna, Cancer Research 53 (1993), 5845.

[20] C. Conrado, work in progress

[21] K. M. Miranda, X. Bu, I. Lorkovic, and P. C. Ford, Inorg. Chem. 36 (1997), 4838.

[22] L. Cheng and G. B. Richter-Addo, The Porphyrin Handbook, K. M. Kadish, K. M. Smith, and R. Guilard (eds.), Vol. 4, Academic Press, New York, 2000, Chpt. 33, and references therein.

[23] I. M. Lorkovic and P. C. Ford, Inorg. Chem. 38 (1999), 1467.

[24] I. M. Lorkovic, K. M. Miranda, B. Lee, S. Bernhard, J. R. Schoonover, and P. C. Ford, J. Am. Chem. Soc. 120 (1998), 11674.

[25] M. Hoshino, Y. Nagashima, H. Seki, M. DeLeo, and P. C. Ford, Inorg. Chem. 37 (1998), 2464.

[26] J. H. Enemark and R. D. Feltham, J. Am. Chem. Soc. 96 (1974), 5002.

[27] (a) T. Takede, R. Irie, Y. Shinoda, and T. Katsuki, Synlett 07 (1999), 1157. (b) J. Mihara, T. Hamada, T. Takede, R. Irie, and T. Katsuki, Synlett 07 (1999), 1160.

[28] C. F. Works and P. C. Ford, J. Am. Chem. Soc. 122 (2000), 7592.

[29] M. de C. T. Carrondo, P. Rudolf, A. Skapski, J. Thornback, and G. Wilkinson, Inorg. Chim. Acta 24 (1977), L95.

[30] C. Works and C. Jocher, studies in progress.

[31] L. E. Laverman, M. Hoshino, and P. C. Ford, J. Am. Chem. Soc. 119 (1997), 12663.

[32] M. Hoshino, L. Laverman, and P. C. Ford, Coord. Chem. Revs. 187 (1999), 75.

[33] L. E. Laverman, A. Wanat, J. Oszajca, G. Stochel, P. C. Ford, and R. van Eldik, J. Amer Chem. Soc 123, (2001) 285.

[34] (a) J. N. Armor, H. A. Scheidegger, and H. Taube, J. Am. Chem. Soc. 90 (1968), 5928. (b) J. N. Armor and S. D. Pell, J. Am. Chem. Soc. 95 (1973), 7625.

[35] K. Suslick and R. Watson, Inorg Chem. 30 (1991), 912.

[36] M. Yamaji, Y. Hama, M. Miyazake, and M. Hoshino, Inorg. Chem. 31 (1992), 932.

[37] M. De Leo and P. C. Ford, J. Am. Chem. Soc. 121 (1999), 1980. 


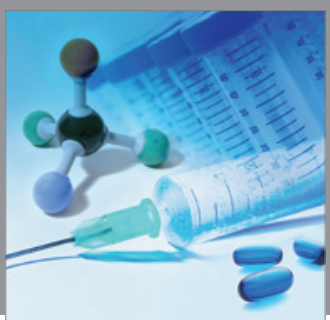

International Journal of

Medicinal Chemistry

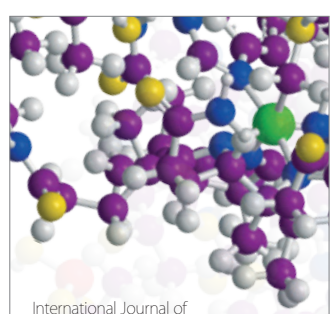

Carbohydrate Chemistry

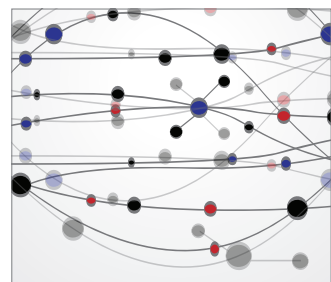

The Scientific World Journal
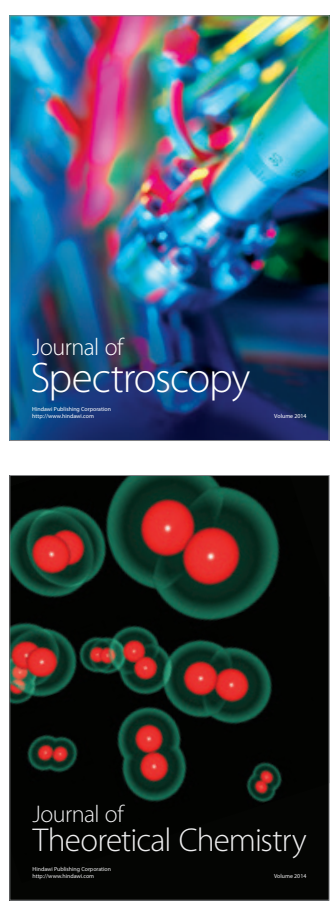
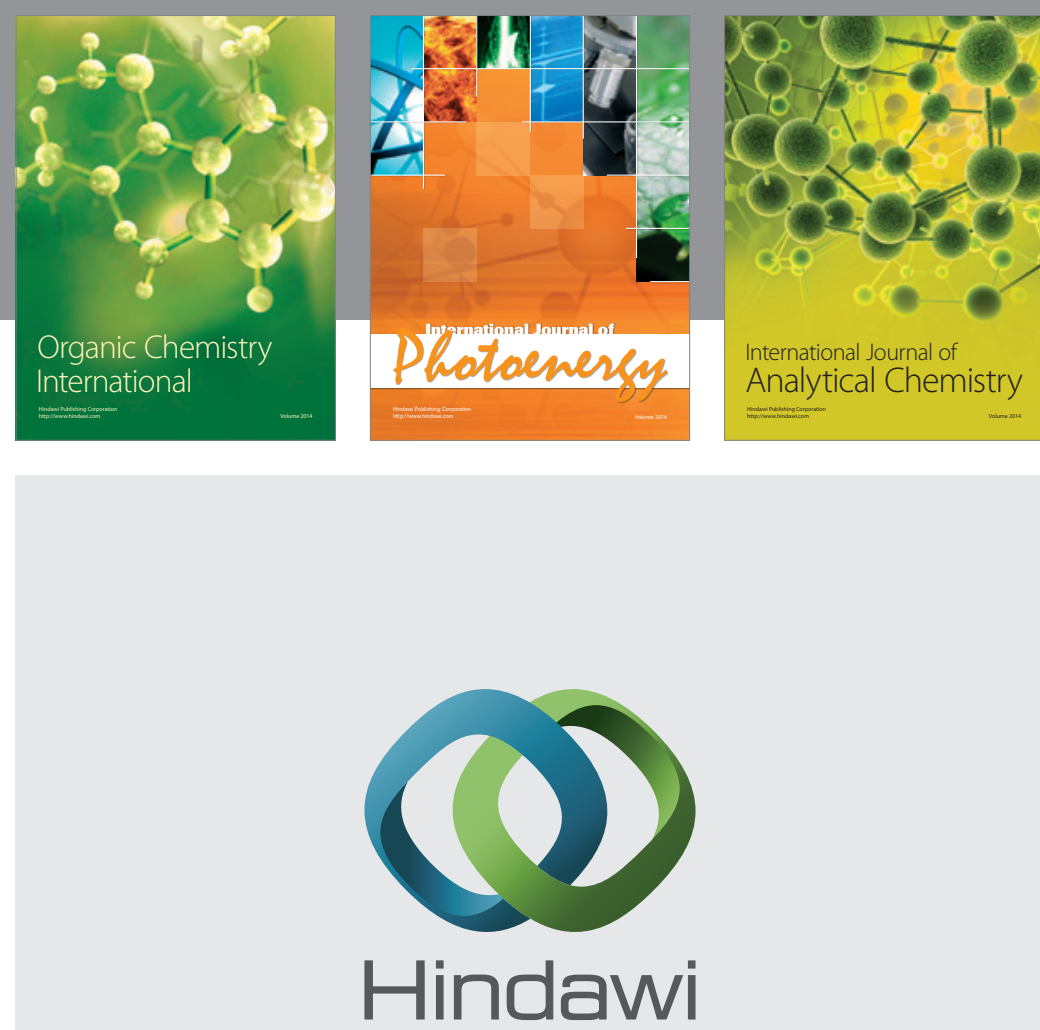

Submit your manuscripts at

http://www.hindawi.com
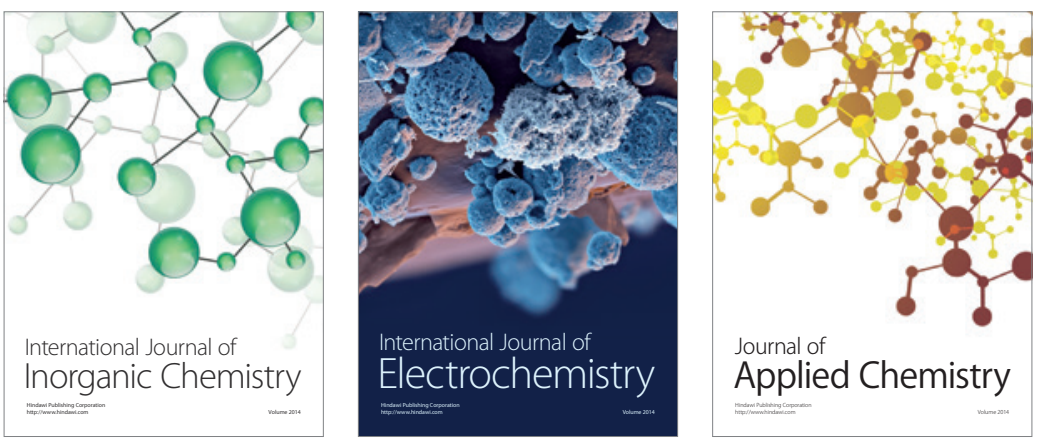

Journal of

Applied Chemistry
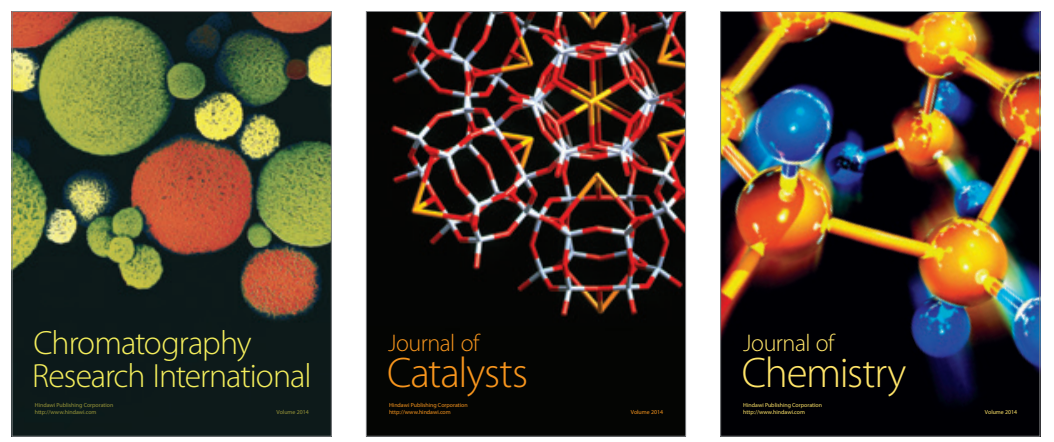
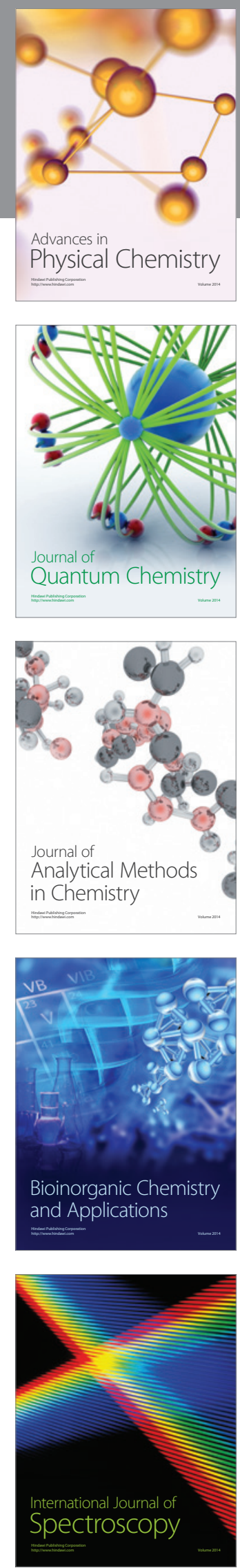